\title{
Hubungan kadar feritin dan asupan energi dengan tingkat kebugaran mahasiswi DIII Gizi STIKes Perintis
}

\author{
Alya Misdhal Rini ${ }^{1}$, Afriwardi $^{2}$, Edison ${ }^{3}$, Widia Dara ${ }^{4}$ \\ 1. Program Studi Pascasarjana IImu Biomedik, Fakultas Kedokteran, Universitas Andalas/STIKes \\ Perintis Padang; 2. Bagian Fisiologi, Fakultas Kedokteran, Universitas Andalas; 3. Bagian IImu \\ Kesehatan Masyarakat, Fakultas Kedokteran, Universitas Andalas; 4. Program Studi Gizi STIKES \\ Perintis Padang.
}

Korespondensi: Alya Misdhal Rini; email: rini.alya1701@gmail.com

\begin{abstract}
Abstrak
Kebugaran jasmani merupakan salah satu indikator kesehatan yang penting. Kebugaran dipengaruhi oleh banyak faktor antara lain feritin di dalam tubuh dan asupan energi. Feritin yang rendah menyebabkan anemia, dan dapat menurunkan tingkat kebugaran fisik. Tujuan: Untuk mengetahui hubungan kadar feritin dan asupan energi dengan tingkat kebugaran pada mahasiswi Prodi DIII Gizi STIKes Perintis Padang. Metode: Desain penelitian cross-sectional, observasi pada seluruh mahasiswi Program Studi DIII Gizi STIKes Perintis Padang. Sampel sejumlah 66 orang. Kadar feritin diperiksa di Balai Laboratorium Kesehatan Sumatera Barat dengan metode ECLIA, asupan energi dengan Food Frequency Questionaire (FFQ), dan tingkat kebugaran dengan metode Harvard Step Test. Analisis statistik yang digunakan adalah T-independen untuk mengetahui hubungan kadar feritin dan asupan energi dengan tingkat kebugaran mahasiswi. Hasil: Didapatkan rerata kadar feritin mahasiswi adalah $86,6 \pm 106,8 \mathrm{ng} / \mathrm{mL}$; rerata asupan energi mahasiswi adalah $1688,4 \pm 484,8 \mathrm{kkal} / \mathrm{hari}$; dan sebagian besar mahasiswi tidak bugar. Analisis statistik menunjukkan ada perbedaan yang signifikan rerata kadar feritin dalam darah dan asupan energi antara responden yang bugar dengan yang tidak bugar $(p<0,05)$. Simpulan: Terdapat hubungan yang signifikan antara kadar feritin dan asupan energi dengan tingkat kebugaran.
\end{abstract}

Kata kunci: kadar feritin; asupan energi; tingkat kebugaran

\begin{abstract}
Physical fitness is one of the important health indicators. Fitness is influenced by many factors, such as ferritin and energy intake. Low ferritin causes anemia and can decrease the level of physical fitness. Objective: To determine the correlation of ferritin concentration and energy intake with level of fitness. Methods: The design was cross sectional, observation on the entire college students of DIII Nutrition Study Program at STIKes Peritis Padang. The total sample were 66 students. Ferritin concentration was checked at Balai Laboratorium Kesehatan West Sumatera by ECLIA, energy intake by Food Frequency Questionaire (FFQ) and level of fitness with Harvard Step Test. Data were analyzed with independent$T$ test to find the correlation of ferritin concentration and energy intake with level of fitness. Results: We obtained, mean concentration of college students' ferritin was $86.6 \pm 106.8 \mathrm{ng} / \mathrm{mL}$; mean of energy intake was $1688.4 \pm 484.8 \mathrm{Cal} /$ day; and most of the students were not fit. Statistical analysis showed there was significant difference in meal concentration of ferritin and energy intake between respondents were fit and not fit ( $p>0.05)$. Conclusion: There is correlation between ferritin concentration and energy intake with level of fitness.
\end{abstract}

Keywords: ferritin levels; energy intake; fitness levels 


\section{PENDAHULUAN}

Kebugaran yang optimal dapat dicapai dengan melakukan aktivitas fisik yang aktif disertai latihan fisik yang benar, teratur, dan terukur. Kemajuan teknologi memberikan berbagai kemudahan dalam beraktivitas, gerak yang dilakukan menjadi berkurang, sehingga kebugaran tubuh pun semakin menurun. ${ }^{1}$

Kandungan feritin yang rendah menyebabkan anemia, dan dapat menurunkan tingkat kebugaran fisik, yang akan berdampak pada penurunan kemampuan melaksanakan aktivitas fisik. Menurunnya kemampuan kerja pada orang yang anemia disebabkan karena menurunnya persediaan oksigen dalam jaringan, gangguan aktivitas sistem elektron, dan pelemahan kemampuan metabolisme energi dalam mitokondria. ${ }^{2}$

Penelitian Cipako (2012) mendapatkan adanya hubungan yang bermakna antara asupan zat besi dengan tingkat kebugaran pada mahasiswi gizi Universitas Indonesia. Semakin tinggi asupan zat besi, semakin tinggi nilai VO2 maksimumnya, yang berarti semakin meningkat kebugarannya. ${ }^{3}$ Pitriani (2012) mendapatkan hasil yang berbeda. la melakukan penelitian pada atlet taekwondo remaja di pemusatan latihan nasional Cipayung, Bogor. Pada penelitian tersebut didapatkan tidak ada hubungan yang signifikan antara feritin dengan tingkat kebugaran atlet. ${ }^{4}$

Remaja merupakan modal penting dalam pembangunan nasional. Oleh karena itu, remaja harus memiliki kesehatan fisik, mental, dan sosial yang baik pula. Peningkatan kebugaran jasmani akan meningkatkan kualitas fisik, dan bagi remaja akan mempengaruhi prestasi belajarnya. Menurut kebugaran jasmani berperan sebesar $41,8 \%$ terhadap prestasi belajar. $^{5}$

Asupan energi juga berpengaruh terhadap kebugaran jasmani. Asupan energi yang berasal dari karbohidrat, protein, dan lemak akan menentukan ketersediaan energi dalam tubuh. Kurangnya asupan kalori dan zat-zat gizi akan berdampak pada berkurangnya kemampuan tubuh dalam melakukan aktivitas, disebabkan terbatasnya persediaan ATP dalam otot yang dibutuhkan untuk kontraksi. Asupan energi tergantung pada pola makan. Pola makan yang baik dan terjaga kualitasnya diperlukan untuk mendapatkan asupan energi yang cukup dan memadai, yang nantinya akan berpengaruh terhadap kebugaran jasmani. ${ }^{6}$

Remaja beranjak dewasa banyak yang mengembangkan pola makan tidak baik, seperti tidak sarapan, makan tidak teratur, dan terlalu banyak mengonsumsi makanan ringan sebagai sumber makanan seharihari. Remaja cenderung memiliki sifat yang konsumtif serta pola konsumsi yang tidak beraturan. $^{7}$

Data Riskesdas 2013 menunjukkan proporsi masyarakat Indonesia yang melakukan aktivitas fisik kurang aktif secara umum adalah $26,1 \%$. Sebanyak 22 provinsi yang masyarakatnya tergolong pada kelompok dengan aktivitas fisik 
kurang aktif berada di atas rata-rata Indonesia, lima tertinggi diantaranya adalah masyarakat provinsi DKI Jakarta (44,2\%), Papua (38,9\%), Papua Barat (37,8\%), Sulawesi Tenggara dan Aceh (masing-masing 37,2\%), sedangkan di Sumatera Barat jumlahnya sebanyak 28,8\%. ${ }^{8}$ Tujuan penelitian untuk mengetahui hubungan kadar feritin dan asupan energi dengan tingkat kebugaran pada mahasiswi Program Studi DIII Gizi STIKes Perintis Padang.

\section{METODE}

Penelitian ini merupakan studi observasional dengan desain cross sectional. Penelitian dilakukan di STIKes Perintis Padang untuk mengumpulkan sampel, dan Balai Laboratorium Kesehatan Sumatera Barat untuk memeriksa kadar feritin, yang dilaksanakan pada bulan April s/d Juni 2018. Populasi pada penelitian ini adalah mahasiswi Program Studi DIII Gizi STIKes Perintis Padang, yang berjumlah 75 orang. Populasi yang memenuhi kriteria sampel pada penelitian ini adalah sebanyak 66 orang mahasiswi, dengan kriteria inklusi dan eksklusi sebagai berikut: (1) Bersedia dijadikan sampel dengan menandatangani surat persetujuan; (2) tidak menderita penyakit kronis yang telah didiagnosis dokter seperti asma, jantung, dan lain-lain, yang dapat diketahui melalui kuesioner $P A R-Q$ and YOU yang dibagikan sebelum tes ketahanan kardio respirasi dilaksanakan; (3) tidak menderita kecacatan fisik; (4) memiliki tekanan darah normal $(120 / 80 \mathrm{mmHg})$ dan denyut nadi normal (60-80/menit). Kriteria eksklusi sebagai berikut: tidak hadir pada saat dilakukan penelitian (setelah 3 kali kunjungan) dan menderita sakit pada saat dilakukan penelitian.

Pengukuran kadar feritin (ng/mL) (konsentrasi kompleks besi-apoferitin, yang merupakan salah satu bentuk utama penyimpanan besi di dalam tubuh) dengan metode ECLIA

(Enhanced Chemiluminescence Immunoassay). Asupan energi diukur dengan wawancara menggunakan kuesioner Formulir FFQ semi kuantitatif dengan hasil ukur asupan rata-rata energi mahasiswi per hari. Kebugaran jasmani adalah kemampuan kesanggupan sistem jantung, pembuluh darah dan paru-paru untuk berfungsi secara optimal dalam mengambil dan menyalurkan oksigen dalam jumlah yang cukup untuk memenuhi tuntutan kerja otot yang diukur dengan metode Harvard Step Test. Hasil pengukuran nya dinyatakan Indeks kebugaran mahasiswi: Bugar, jika $\geq 65$ dan tidak bugar $<65$.

Hasil penelitian diolah secara statistik, dan dilakukan uji normalitas KolmogorovSmirnov untuk melihat apakah data terdistribusi normal atau tidak. Jika data terdistribusi normal, maka dilakukan uji Tindependen untuk mengetahui hubungan kadar feritin dan asupan energi dengan tingkat kebugaran mahasiswi.

\section{HASIL DAN PEMBAHASAN}

Telah dilakukan penelitian observasional dengan desain cross sectional pada mahasiswi Program Studi DIII Gizi STIKes 
Perintis Padang dengan sampel sebanyak 66 orang yang berumur 18 sampai 23 tahun. Pada responden dilakukan pemeriksaan ketahanan kardio respirasi, pemeriksaan kadar feritin dalam darah, dan penilaian asupan energi. Penelitian di lapangan dilakukan dari bulan April sampai dengan Juni 2018. Karakteristik responden secara umum dapat dilihat pada berikut ini.

Tabel 1. Distribusi Responden Berdasarkan Umur

\begin{tabular}{ccc}
\hline Variabel & Rata-rata \pm SD & Min-Maks \\
\hline Umur (th) & $20,1 \pm 1,1$ & $18-23$ \\
\hline
\end{tabular}

Tabel 1 menunjukkan bahwa rerata umur responden adalah 20,0 tahun $\pm S D$.

Rerata Kadar Feritin dalam Darah, Asupan Energi, \% AKG, dan Tingkat Kebugaran

Tabel 2. Rerata Kadar Feritin dalam Darah, Asupan Energi, \% AKG dan Rerata Kebugaran

\begin{tabular}{lcc}
\hline \multicolumn{1}{c}{ Variabel } & Rata-rata \pm SD & Min-Maks \\
\hline $\begin{array}{l}\text { Kadar Feritin } \\
\text { dalam Darah }\end{array}$ & $86,6 \pm 106,8$ & $\begin{array}{l}11,8- \\
728,0\end{array}$ \\
(ng/ml) & & \\
$\begin{array}{l}\text { Asupan } \\
\text { Energi }\end{array}$ & $1688,4 \pm 484,8$ & $892,2-$ \\
(Kkal/hari) & & 3099,8 \\
$\%$ AKG & $73,6 \pm 21,3$ & $37,9-$ \\
$\begin{array}{l}\text { Asupan } \\
\text { Energi }\end{array}$ & & 137,8 \\
Indeks & $39,7 \pm 18,6$ & $7,1-80,5$ \\
kebugaran & & \\
\hline
\end{tabular}

Tabel 2 menunjukkan bahwa rerata kadar feritin dalam darah 86,6 $\pm 106,8 \mathrm{ng} / \mathrm{mL}$. Kadar feritin terendah adalah $11,8 \mathrm{ng} / \mathrm{mL}$ dan kadar feritin tertinggi adalah 728,0 $\mathrm{ng} / \mathrm{mL}$ (batas normal kadar feritin berdasarkan reagen kit human feritin untuk perempuan adalah 13-150 ng/mL). Rerata asupan energi per hari adalah $1688,4 \pm 484,8 \mathrm{kkal} / \mathrm{hari}$. Asupan terendah per hari adalah 892,2 kkal dan tertinggi adalah 3099,8 kkal (Asupan energi berdasarkan Angka Kecukupan Gizi untuk wanita umur 19-29 tahun adalah 2250 $\mathrm{kkal} /$ hari), dan rerata persentase AKG untuk asupan energi adalah 73,6\%. Sementara itu rerata indeks kebugaran adalah $39,7 \pm S D$. Rata-rata ini termasuk ke dalam rerata tidak bugar, sementara itu distribusi responden berdasarkan tingkat kebugaran dapat dilihat pada tabel 3 berikut ini:

Tabel 3. Distribusi Responden Berdasarkan Tingkat Kebugaran

\begin{tabular}{lcc}
\hline Tingkat kebugaran & $\mathrm{f}$ & $\%$ \\
\hline Bugar & 6 & 9,1 \\
Tidak bugar & 60 & 90,9 \\
\hline
\end{tabular}

Tabel 3 menunjukkan bahwa lebih dari sebagian besar responden (90,9\%) memiliki tingkat kebugaran yang tidak bugar.

\section{Uji Normalitas Data}

Berdasarkan hasil uji normalitas data didapatkan bahwa kadar feritin dalam darah tidak terdistribusi normal dan asupan energi sudah terdistribusi normal. Selanjutnya dilakukan transformasi data dengan Lg10 pada data kadar feritin dalam darah, dan dilakukan kembali uji normalitas data dan didapatkan data kadar feritin dalam darah yang sudah ditransformasi terdistribusi normal $(p>0,05)$. Selanjutnya untuk melihat hubungan kadar feritin dalam darah dan asupan energi dengan tingkat kebugaran digunakan uji t independen.

Rerata Kadar Feritin dalam Darah Berdasarkan Tingkat Kebugaran 
Mahasiswi Program Studi DIII Gizi STIKes Perintis Padang

Tabel 4 menunjukkan bahwa rerata kadar feritin pada responden yang bugar adalah $225,8 \mathrm{ng} / \mathrm{mL} \pm S D$, sedangkan responden yang tidak bugar memiliki rerata kadar feritin $72,7 \pm S D$. Dari uji statistik didapatkan ada perbedaan yang signifikan rerata kadar feritin dalam darah antara responden yang bugar dengan yang tidak bugar $(p<0,05)$.

Tabel 4. Rerata Kadar Feritin dalam Darah Berdasarkan Tingkat Kebugaran Mahasiswi Program Studi DIII Gizi STIKes Perintis Padang

\begin{tabular}{|c|c|c|c|}
\hline & \multicolumn{2}{|c|}{ Tingkat Kebugaran } & \multirow{2}{*}{$p$ value } \\
\hline & Bugar & Tidak Bugar & \\
\hline $\begin{array}{l}\text { Rata-rata } \pm S D \text { Kadar Feritin dalam Darah }(\mathrm{ng} / \mathrm{ml}) \\
\mathrm{f}\end{array}$ & $\begin{array}{c}225,8 \pm 100,8 \\
6\end{array}$ & $\begin{array}{l}72,7 \pm 72,3 \\
60\end{array}$ & 0,001 \\
\hline
\end{tabular}

Rerata Asupan Energi Berdasarkan Tingkat Kebugaran Mahasiswi Program Studi DIII STIKes Perintis Padang

Berdasarkan tabel 5 dapat dilihat bahwa rerata asupan energi pada responden yang bugar adalah 2110,3 kkal/hari $\pm S D$, sedangkan responden yang tidak bugar mempunyai rerata asupan energi

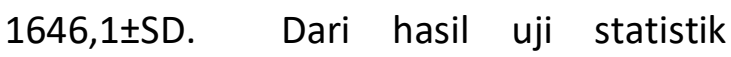
didapatkan ada perbedaan yang signifikan asupan energi per hari antara responden yang bugar dengan yang tidak bugar $(p<0,05)$.

Tabel 5. Rerata Asupan Energi Berdasarkan Tingkat Kebugaran Mahasiswi Program Studi DIII Gizi STIKes Perintis Padang

\begin{tabular}{|c|c|c|c|}
\hline & \multicolumn{2}{|c|}{ Tingkat Kebugaran } & \multirow{2}{*}{$p$ value } \\
\hline & Bugar & Tidak Bugar & \\
\hline Rata-rata $\pm S D$ Asupan Energi (kkal/hari) & $2110,3 \pm 495,3$ & $1646,2 \pm 467,2$ & 0,024 \\
\hline f & 6 & 60 & \\
\hline
\end{tabular}

Distribusi Responden Berdasarkan Tingkat Kebugaran

Sebagian besar responden (90,9\%) berada pada tingkat kebugaran yang tidak bugar. Hasil penelitian ini senada dengan penelitian-penelitian sebelumnya antara lain Carnethon yang melakukan penelitian pada remaja dan orang dewasa Amerika dan mendapatkan $33,6 \%$ remaja dan $13,9 \%$ orang dewasa memiliki kebugaran yang rendah. ${ }^{9}$ Di Indonesia tahun 2009 menemukan hal yang tidak jauh berbeda yaitu hanya $1,08 \%$ yang masuk dalam kategori baik sekali; $4,07 \%$ baik dan $13,55 \%$ sedang sisanya sekitar 43,90\% dikategorikan kurang; dan 37,40\% kurang sekali. ${ }^{10}$ Penelitian pada mahasiswa Pendidikan Dokter Universitas Andalas, juga menemukan hal yang sama, yaitu dari 72 mahasiswa yang diobservasi terdapat 66 orang $(91,7 \%)$ mahasiswa yang memiliki ketahanan kardio respirasi yang buruk. ${ }^{11}$

Berdasarkan hasil penelitian ini dan penelitian-penelitian sebelumnya, dapat disimpulkan bahwa tingkat kebugaran dari berbagai negara dan kalangan usia semakin lama semakin menurun. 
Rerata Kadar Feritin dalam Darah Responden

Hasil penelitian ini menunjukkan bahwa rerata kadar feritin dalam darah responden adalah $86,6 \mathrm{ng} / \mathrm{mL} \pm S D$. Kadar feritin terendah adalah $11,8 \mathrm{ng} / \mathrm{mL}$ dan kadar feritin tertinggi adalah $728 \mathrm{ng} / \mathrm{mL}$. Sesuai dengan reagen yang digunakan dalam penelitian ini, kadar normal feritin dalam darah untuk perempuan usia 17-60 tahun adalah $13-150 \mathrm{ng} / \mathrm{mL}$, rerata kadar feritin dalam darah responden ini berada dalam batas normal.

\section{Rerata Asupan Energi Responden}

Kebutuhan gizi terutama energi tergantung dari umur, aktivitas fisik dan jenis kelamin. Sesuai Angka Kecukupan Gizi (AKG) yang dianjurkan, kecukupan energi untuk wanita usia 19-29 tahun adalah 2250 kkal/hari (AKG, 2013). Hasil analisis terhadap asupan energi responden menunjukkan rerata asupan energi responden per hari adalah 1985 kkal. Jika dibandingkan dengan Angka Kecukupan Gizi, rerata asupan energi responden berada di bawah Angka Kecukupan Gizi (AKG) yang dianjurkan. Hasil penelitian ini sejalan dengan hasil yang ditemukan Riskesdas tahun 2010 secara nasional, rerata asupan energi per hari untuk usia 19-29 tahun adalah 1998 kkal/hari. ${ }^{12}$

Kebutuhan energi merupakan faktor yang cukup dominan dan perlu di perhatikan. Responden yang mempunyai aktivitas yang lebih akan memerlukan energi lebih banyak di bandingkan dengan responden yang tidak banyak melakukan aktivitas.
Terbukti responden pada penelitian ini adalah mahasiswi yang memiliki aktivitas rutin mengikuti perkuliahan dari pagi hingga sore dan tidak melakukan aktivitas fisik yang terlalu berat.

Bila asupan energi kurang dari makanan dibandingkan dengan energi yang dikeluarkan maka tubuh akan mengalami keseimbangan negatif akibatnya berat badan kurang dari berat badan seharusnya (ideal), bila terjadi pada masa pertumbuhan maka akan menghambat proses pertumbuhan dan pada orang dewasa menyebabkan penurunan berat badan dan kerusakan jaringan. Asupan energi yang kurang juga menyebabkan cadangan energi yang tersimpan dalam tubuh terkuras untuk menghasilkan energi dan akhirnya akan berakibat pada penurunan berat badan.

Pada penelitian ini kurangnya asupan energi disebabkan karena alasan responden yang lagi menjaga bentuk tubuh, sehingga mereka cenderung mengurangi asupan makanan.

Hubungan Kadar Feritin dalam Darah dengan Tingkat Kebugaran Mahasiswi Program Studi DIII Gizi STIKes Perintis Padang

Hasil penelitian ini menunjukkan bahwa berdasarkan uji statistik ditemukan ada perbedaan yang signifikan $(p<0,05)$ rerata kadar feritin dalam darah responden yang memiliki tingkat kebugaran yang bugar dengan yang tidak bugar. Dari hal ini disimpulkan bahwa kadar feritin dalam 
darah adalah salah satu faktor yang berhubungan dengan tingkat kebugaran.

Hasil penelitian ini koheren dengan penelitian yang dilakukan Mainous, dengan membuktikan bahwa kadar feritin yang rendah berkaitan dengan tingkat kebugaran. Kecenderungan ini disebabkan kadar feritin dalam darah memegang peranan penting dalam proses pembentukan hemoglobin dan hemoglobin adalah pembawa oksigen ke otot-otot. ${ }^{13}$

Fungsi hemoglobin dalam energi adalah sebagai penyuplai oksigen. Pada proses metabolisme yang membutuhkan oksigen (energi), akan menghasilkan energi yang besar yang digunakan untuk aktivitas yang berdurasi lama terutama yang memerlukan daya tahan. Berbeda dengan energi anaerob pengadaan energi pada energi aerob lebih hemat, tetapi tidak dapat menyediakan energi dalam jumlah yang banyak dalam waktu yang singkat. ${ }^{6}$

Sumber energi utama yang digunakan untuk menyediakan energi bagi otot untuk berkontraksi berasal dari simpanan karbohidrat dan lemak. Lemak yang disimpan di dalam tubuh hanya dapat dipecah melalui proses metabolisme energi untuk menghasilkan ATP, namun proses ini juga memerlukan ketersediaan karbohidrat agar proses pembakarannya menjadi sempurna. ${ }^{14}$

Apabila glukosa masuk dalam sel, maka molekul glukosa tersebut dengan serangkaian reaksi kimia diproses menjadi energi, yang disebut peristiwa glikolisis.
Energi yang dikeluarkan digunakan untuk membentuk ATP kembali dan menghasilkan 2 ATP. Reaksi ini tidak efisien, karena dari $1 \mathrm{~mol}$ ( $180 \mathrm{gr}$ ) glikogen hanya membentuk 2 ATP sedangkan bila dengan pertolongan oksigen akan menghasilkan 36 atau 38 ATP. ${ }^{15,16}$

Feritin yang bersirkulasi di dalam darah mencerminkan simpanan besi di dalam tubuh. ${ }^{17}$ Feritin adalah indikator terbaik dari simpanan besi seseorang. Menurunnya tingkat kebugaran karena kekurangan zat besi disebabkan oleh dua hal, antara lain kurangnya enzim-enzim yang terlibat dalam metabolisme energi dan menurunnya hemoglobin darah, sehingga metabolisme energi di dalam otot akan terganggu dan terjadi penumpukan asam laktat sehingga menyebabkan rasa lelah. ${ }^{18}$ Selain itu dengan cukupnya zat besi tubuh maka akan mampu mempercepat metabolisme energi sehingga dapat mengganti secara cepat kekurangan energi untuk aktivitas fisik. Jika proses ini selalu terjaga dengan cadangan zat besi yang cukup maka tingkat kebugaran akan terjaga dengan baik. ${ }^{19}$

Hasil penelitian ini juga sejalan dengan yang dilakukan oleh Indriani yang melakukan penelitian tentang peningkatan status besi dan kebugaran fisik pekerja wanita usia subur dan menyimpulkan pemberian suplemen zat besi 3 kali sehari selama 10 minggu mampu meningkatkan kadar feritin dan kebugaran fisik pekerja wanita usia subur. ${ }^{20}$ 
Hubungan Asupan Energi Dengan Tingkat Kebugaran Program Studi DIII Gizi STIKes Perintis Padang

Hasil penelitian ini menunjukkan secara energi terdapat perbedaan rerata asupan energi antara responden yang memiliki tingkat kebugaran yang bugar dengan yang tidak bugar. Berdasarkan hal tersebut dapat dikatakan bahwa asupan energi merupakan hal yang berhubungan dengan tingkat kebugaran. Hasil penelitian ini senada dengan penemuan Cipako yang menyebutkan semakin tinggi asupan energinya semakin tinggi nilai VO2 maksimumnya (tingkat kebugarannya). ${ }^{3}$

Energi dari makanan di transfer ke molekul penyimpan yang disebut Adenosine Triphosphate (ATP). Kontraksi otot untuk setiap olahraga atau aktivitas fisik yang dihasilkan oleh gerakan menggunakan otot, didukung oleh energi yang dilepaskan dari pemisahan ikatan berenergi tinggi fosfat dari ATP. Meskipun ATP adalah sumber energi langsung untuk kontraksi otot, jumlah ATP yang hadir dalam otot sangat kecil (hanya sekitar 85 gram) yang harus terus diisi ulang atau akan habis setelah beberapa detik olahraga intensitas tinggi. ATP diisi kembali oleh dua energi yang terpisah, sistem energi menghasilkan ATP tanpa adanya oksigen dari tempat penyimpanan small ATP-creatine phosphate (CP) dan energi laktat dan energi atau menggunakan oksigen. ${ }^{21}$

Hasil penelitian ini juga sama dengan penelitian Sugiarto yang melakukan penelitian tentang hubungan asupan energi, protein dan suplemen dengan tingkat kebugaran menyimpulkan ada hubungan yang signifikan antara asupan energi dengan tingkat kebugaran peserta fitness Virenka Gym Bantul Surabaya. ${ }^{22}$

Dalam melakukan aktivitas fisik dan menjaga kebugaran tubuh harus selalu tersedia cadangan energi yang sewaktuwaktu dapat dimobilisasikan untuk menghasilkan energi. Cadangan energi tersimpan dalam otot dan hati sebagai glikogen. Jika cadangan glikogen dalam tubuh sedikit, maka tubuh akan cepat lelah karena kehabisan tenaga. Teori tersebut terbukti pada penelitian ini yang mendapatkan hasil asupan energi responden yang memiliki tingkat kebugaran yang bugar memiliki asupan energi $2110,3 \mathrm{kkal} /$ hari atau $98 \%$ dari AKG yang menganjurkan $2250 \mathrm{kkal} / \mathrm{hari}$ untuk remaja usia 19-29 tahun. ${ }^{23}$

\section{SIMPULAN}

Rerata kadar feritin mahasiswi Prodi DIII Gizi STIKes Perintis Padang adalah 86,6 $\mathrm{ng} / \mathrm{mL} \pm \mathrm{SD}$. Rerata asupan energi mahasiswi Prodi DIII Gizi STIKes Perintis Padang adalah 1688,4 kkal/hari $\pm S D$. Sebagian besar responden (90,9\%) memiliki tingkat kebugaran yang tidak bugar. Ada hubungan antara kadar feritin dalam darah dengan tingkat kebugaran mahasiswi Prodi DIII Gizi STIKes Perintis Padang. Ada hubungan antara asupan energi dengan tingkat kebugaran mahasiswi Prodi DIII Gizi STIKes Perintis Padang. 


\section{UCAPAN TERIMA KASIH}

Terima kasih kepada Pimpinan STIKes

Perintis Padang dan Balai Laboratorium
Kesehatan Sumatera Barat dan seluruh pihak yang terlibat dalam penelitian ini.

\section{DAFTAR PUSTAKA}

1. Departemen Kesehatan RI. Panduan Kesehatan Olah Raga bagi Petugas Kesehatan. Jakarta; 2002.

2. Chandrawali. Pengaruh Suplementasi Zat Besi dengan Asam Folat, Vitamin A, dan Vitamin C terhadap Peningkatan Kadar Hb dan Produktivitas Kerja pada Tenaga Kerja Wanita di PT. South Suco Makasar. [Tesis]. Makassar: Fakultas Ilmu Kesehatan Masyarakat Universitas Hasanuddin; 2007.

3. Cipako ES. Hubungan Status Gizi, Asupan Gizi, dan Aktivitas Fisik dengan VO2max pada Mahasiswi Program Studi Gizi. [Tesis]. Jakarta: Fakultas IImu Masyarakat Universitas Indonesia; 2012.

4. Pitriani A. Hubungan Konsumsi Pangan dan Status Gizi dengan Tingkat Kebugaran Atlet Taekwondo Remaja di Pemusatan Latihan Nasional Cipayung Bogor. [Tesis]. Bogor: Fakultas Ekologi Manusia Institut Teknologi Bogor; 2012.

5. Susanto I. Hubungan Tingkat Kesegaran Jasmani dengan Prestasi Belajar Siswa Kelas VI Sekolah Dasar Negeri Potorono Kecamatan Banguntapan Kabupaten Bantu. [tesis]. Yogyakarta: Fakultas Ilmu Keolahragaan Universitas Negri Yogyakarta; 2013.

6. Afriwardi. IImu Kedokteran Olahraga. Jakarta: EGC; 2011. p.115-26.

7. Santrock JW. Perkembangan Anak. Jakarta: Erlangga; 2007.

8. Kementerian Kesehatan RI. Riset Kesehatan Dasar 2013. Jakarta: Kementerian Kesehatan RI; 2013.

9. Carnethon MR, Jacobs DR, Sidney S, Sternfeld B, Gidding SS, Shoushtari C, et al. A longitudinal study of physical activity and heart rate recovery: CARDIA, 1987-1993. Med Sci Sports Exerc. 2005; 37(4):606-12. doi: 10.1249/01.mss.0000158190.56061.32. [PubMed].

10. Cassandra Y. Hubungan Status Gizi, Latihan Fisik Asupan Energi dan Zat Gizi dengan Status Kebugaran pada Mahasiswa S1. [Skripsi]. Depok: Fakultas Kesehatan Masyarakat Universitas Indonesia; 2011.

11. Lubis HM, Sulastri D, Afriwardi A. Hubungan Indeks Massa Tubuh dengan Ketahanan Kardiorespirasi, Kekuatan dan Ketahanan Otot dan Fleksibilitas pada Mahasiswa Laki-Laki Jurusan Pendidikan Dokter Universitas Andalas Angkatan 2013. Jurnal Kesehatan Andalas. 2015; 4(1):14250. [Abstract/FREE Full-Text].

12. Badan Penelitian dan Pengembangan Kesehatan. Riset Kesehatan Dasar 2010. Jakarta: Kementerian Kesehatan RI; 2010.

13. Mainous AG, Diaz VA. Relation of serum ferritin level to cardiovascular fitness among young men. Am J Cardiol. 2009; 103(1):115-8. doi: 10.1016/j.amjcard.2008.08.046. [PubMed].

14. Wiarto. Fisiologi dan Olahraga. Yogyakarta: Graha IImu; 2013.

15. Wulandari N, penerjemah. Biokimia Harper. Jakarta: ECG; 2009.

16. McArdle W, Katch F, Katch V. Exercise Physiology: Nutrition, Energy, and Human Performance. $7^{\text {th }}$ Edition. Philadelphia: Lippincott Williams \& Wilkins; 2009. 
17. Yuniritha, Sulistyowati Y. Metabolisme Zat Gizi. Yogyakarta: Trans Medika; 2015.

18. Nuraini R. Hubungan Tingkat Konsumsi Zat Besi dan Vitamin C dengan Kesegaran Jasmani Anak Sekolah Dasar Negeri Kartasura 1 Kecamatan Kartasura Kabupaten Sukoharjo Jawa Tengah. [Skripsi]. Jawa Tengah: Fakultas IImu Kesehatan Universitas Muhammadiyah Surakarta; 2010.

19. Widjajakusumah M, Tanzil A, penerjemah. Buku Ajar Fisiologi Kedokteran. Jakarta: EGC; 2012.

20. Indriani $Y$, Khomsan A, Sukandar D, Riyadi H, Zuraida R. Peningkatan status besi dan kebugaran fisik pekerja wanita usia subur. Jurnal Gizi dan Pangan. 2011; 6(3):178-85. DOI: 10.25182/jgp.2011.6.3.178-185.

21. Nieman D. Exercise Testing and Prescription a Health-Related Approach. $7^{\text {th }}$ Edition. New York City: McGraw-Hill; 2011.

22. Sugiarto. Hubungan Asupan Energi, Protein dan Suplemen dengan Tingkat Kebugaran. Media Ilmu Keolahragaan Indonesia. 2012; 2(2):1-8. [Abstract/FREE Full-Text].

23. Moehji S. Ilmu Gizi. Edisi I. Jakarta: PT. Bharatara Niaga Media; 2003. 